\title{
EFFECT OF SELENIUM SUPPLEMENTATION IN PIG FEED ON SLAUGHTER VALUE AND PHYSICOCHEMICAL AND SENSORY CHARACTERISTICS OF MEAT*
}

\author{
Dariusz Lisiak $^{1 \bullet}$, Piotr Janiszewski ${ }^{1}$, Tadeusz Blicharski², Karol Borzuta ${ }^{1}$, Eugenia Grześkowiak ${ }^{1}$, \\ Beata Lisiak ${ }^{1}$, Krzysztof Powałowski ${ }^{1}$, Łukasz Samardakiewicz ${ }^{1}$, Martyna Batorska ${ }^{3}$, \\ Katarzyna Skrzymowska ${ }^{4}$, Anna Hammermeister ${ }^{4}$
${ }^{1}$ Department of Primary Meat Production, Prof. Wacław Dąbrowski Institute of Agricultural and Food Biotechnology, Głogowska 239, 60-111 Poznań, Poland
${ }^{2}$ Institute of Genetics and Animal Breeding of the Polish Academy of Sciences in Jastrzębiec, Postępu 1, 05-552 Magdalenka, Poland
${ }^{3}$ Division of Swine Breeding, Department of Animal Breeding, Warsaw University of Life Sciences, Ciszewskiego 8, 02-786 Warszawa, Poland
${ }^{4}$ Polish Pig Breeders and Producers Association “POLSUS”, Ryżowa 90, 02-495 Warszawa, Poland
•Corresponding author: darek.lisiak@ipmt.waw.pl

\begin{abstract}
The aim of the study was to examine the assimilability of organic and inorganic selenium supplied as an additive to pig feed. The influence of both selenium forms on pig slaughter value as well as on the physicochemical and sensory characteristics of meat was also examined (experiment I). An attempt to establish the distribution of selenium in the body of experimental fatteners was made (experiment II). Experiment I was performed on 20 carcasses of crossbred pigs of (Polish Large White $\times$ Polish Landrace) $\times$ Duroc genotype and experiment II was carried out on 45 samples of longissimus and semimembranosus muscles taken from fatteners of the same genotype (PLW $\times$ PL $\times$ Duroc). The results obtained indicated that selenium supplementation in the diet had no impact on slaughter performance, meat quality and most physicochemical and sensory characteristics of meat. Selenium was found to have no significant effect on meat colour. The meat water holding capacity (WHC) was lower in the group of pigs fed organic selenium. The highest selenium concentration was found in the semimembranosus muscle of fatteners receiving the inorganic selenium additive.
\end{abstract}

Key words: pigs, selenium, assimilability, meat quality

Selenium is regarded as an essential microelement in the diets of humans and animals. It plays an essential role as an antioxidant and improves immunity. Clinical research has proved that selenium lowers the risk of tumours (Hathcock, 2004;

*This study was carried out within the project "BIOFOOD - innovative, functional products of animal origin" No. POIG.01.01.02-014-090/09. 
Mahan et al., 2005). Both the deficiency and surplus of selenium in a diet causes many disorders (e.g. liver necrosis, higher tumour risk, anaemia, atrophy of internal organs, skin diseases) (Dębski, 2007; Hathcock, 2004). Selenium deficiency may also induce reproductive problems, e.g. fewer piglets in a litter and higher piglet mortality. Selenium also has a positive effect on semen quality (better viability of spermatozoa). Currently, the recommended daily intake of selenium is $55 \mu \mathrm{g}$ for women and $70 \mu \mathrm{g}$ for men, which is on average $1 \mu \mathrm{g} \mathrm{Se} / \mathrm{kg}$ of body weight per day (Wąsowicz et al., 2003). The maximum selenium daily intake has been set at the level of $1,540 \mu \mathrm{g} /$ per day. Intake exceeding this limit is toxic for people and too large a selenium dose may cause negative effects. At the same time it is worth stressing that inorganic selenium has a more severe effect than its organic form (Ghany Hefnawy and Tórtora-Pérez, 2010). Dietary selenium may be in the form of inorganic (e.g. selenites and selenates) and organic compounds (e.g. selenomethionine and selenocysteine). Numerous research indicates that organic forms are easily assimilable and play a more important role than inorganic ones (Mahan et al., 1999). Cereal products, meat and meat products, vegetables, milk, eggs and fish are selenium sources in the human diet. Polish researchers have reported that meat and meat products are the sources of $19.6 \%$ and $16.5 \%$ of selenium, respectively (Zagrodzki, 2000; Marzec et al., 2002; Hordyjewska and Pasternak, 2004). Hence, the production of meat with higher selenium levels that fully meet selenium demand, seems beneficial.

The aim of the study was to examine the assimilability of organic and inorganic selenium supplied as an additive to pig feed. The influence of both selenium forms on pig slaughter value as well as on the physicochemical and sensory characteristics of meat was also examined. An attempt to establish the distribution of selenium in the body of experimental fatteners was also made.

\section{Material and methods}

\section{a. experiment I}

An analysis was carried out on 20 fattening pigs of (Polish Large White $\times$ Polish Landrace) $\times$ Duroc genotype. The fatteners were divided into two groups with the same number of animals. The experimental group was supplemented with an additive of $1 \mathrm{mg} / \mathrm{kg}$ feed of organic selenium in the second fattening stage. The control group received no dietary selenium additive and the fatteners in both groups came from the same farm. The same fattening conditions were applied in both experimental groups. The pigs were kept in individual pens with permanent access to water. The fatteners were fed with a complete balanced feed based on cereal meal (barley, wheat) supplied with extracted meal (soy and rape) and $2.5 \%$ of premix with the selenium additive (experimental group) produced by Trouw Nutrition Poland. The feed portions were prepared according to Nutrient Requirements of Pigs (1993). Both organic and inorganic selenium was added to the feed. The organic form originated from selenium yeast whereas the inorganic selenium was in the form of sodium selenate (called E8 in the European Union). The animals were fed with Inntaler all- 
mash mixtures and also with supplementary mixtures known as MPU-premixes. The standard supplementary feed mixture contained $15 \mathrm{mg} / \mathrm{kg}$ of inorganic selenium. In the first fattening stage $3 \%$ of the supplementary mixture was added to the feed $(0.45 \mathrm{mg} / \mathrm{kg} \mathrm{Se}$ in an all-mash mixture). In the second fattening stage $2.5 \%$ of the supplementary mixture was added to the feed, i.e. $0.38 \mathrm{mg} / \mathrm{kg}$ of selenium in the feed (protein components as well as crushed cereal meal were also a source of selenium but it was not included in the total feed selenium content). The feed was supplied according to the Nutrient Requirements of Pigs (1993). The ad libitum scheme was used in both fattening stages. Approximately $75 \mathrm{~kg}$ of feed per day per trough was served in two portions. One feeding trough provided the feed in two compartments with approximately 10 pigs in each.

The fatteners were slaughtered in the "DUDA S.A." slaughterhouse according to the current regulations. Carcass slaughter traits were assessed on the slaughter line. Then measurements of average backfat thickness were taken in 5 points. The carcass lean meat content (\%) was estimated with ultrasound equipment Ultra-Fom 300. Electrical conductivity in the LD muscle was measured on the left side of the carcass that was left hanging after 24 hours of cooling. Samples were then taken from the lumbar part of the longissimus muscle in order to run further meat laboratory tests. The following measurements were taken in the laboratory: $\mathrm{pH}_{24}$; $\mathrm{WHC}$ (water holding capacity) - using the Grau-Hamm method (1952); drip loss and cooking loss - based on the differences in samples' weight; meat colour - with a Minolta CR300 colorimeter; basic meat composition (PN-ISO 1442:2000, PN-ISO 1444:2000); shear force - with a Zwick device and Warner-Bratzler attachment; sensory evaluation was done on a 5-point scale, taking 5 as the best value (PN-ISO 4121:1998).

The results of the measurements were statistically analysed by calculating the mean values, standard deviations and single factor variance analysis (ANOVA). Average value comparisons between the genetic groups were made using the Duncan test.

\section{b. experiment II}

The experiment was carried out on 45 fatteners of the same genotype (PLW $\times$ PL $\times$ Duroc), which were divided into 3 groups. In the experimental groups different forms of selenium were added to the feed: organic or inorganic in the same amount of $0.5 \mathrm{mg} / \mathrm{kg}$ of feed $(\mathrm{n}=17, \mathrm{n}=15$ respectively). Inntaler developed two special supplementary feed mixtures: one with higher inorganic selenium content and the other only with organic selenium form, in order to prepare experimental all-mash feed with $0.5 \mathrm{Se}$ per $\mathrm{kg}$ of feed. The pigs were fed with selenium enriched feed in stage II of the fattening period (over $60 \mathrm{~kg}$ live weight). The fatteners in the control group received the feed without selenium additive $(\mathrm{n}=13)$. All measurements and assessments were done according to the methodology described in point a) above. Additionally, the following samples were taken in experiment II in order to assess the level of selenium: semimembranosus muscle, biceps femoris muscle, triceps brachii muscle as well as samples of bacon, neck, backfat, liver and kidneys. Selenium content was assessed with atomic absorption spectrometry using electro-thermal atomization according to the procedures of the Institute of Agricultural and Food Biotechnology (PB-ZAŻ 12, 2010). The results were statistically analysed as described in point a) above. 


\section{Results}

\section{a. experiment I}

Based on the performed analysis it was established that the supplementation of selenium in pig feed did not have any significant impact on slaughtering performance (Table 1). The fatteners from all groups represented a similar level of carcass lean meat (approx. 55\%) and backfat thickness (approx. $24 \mathrm{~mm}$ - average of 5 measurement points). However, the fatteners from the control group were slightly heavier than from the experimental group, reaching 84.23 and $79.54 \mathrm{~kg}$, respectively. Meat quality assessment results as well as the majority of the physicochemical characteristics of meat did not show any statistically significant differences either. Based on acidity measurements taken 24 hours after slaughtering and electrical conductivity (PE 24h) it was established that there were no meat quality deviations in any of the groups (Table 2). Positive results of meat quality were obtained in both groups. The tested meat showed appropriate colour parameters $\left(\mathrm{L}^{*} \mathrm{a}^{*} \mathrm{~b}^{*}\right)$ and $\mathrm{WHC}$, a relatively low drip loss at thermal processing as well as optimal basic composition; for example, intramuscular fat content in the experimental group was approx. $1.8 \%$ but in the control group it was slightly lower. A statistically significant difference was observed in meat drip loss which was higher in the control group $(6.77 \%)$ than in the experimental group (5.63\%). Sensory assessment showed statistically significant differences in cooked meat flavour which was more favourable in the experimental group with the selenium additive. Other sensory traits did not show statistically significant differences (Table 3).

Table 1. Slaughter value of fattening pigs in the studied groups - experiment I

\begin{tabular}{|c|c|c|c|c|c|}
\hline \multirow[t]{2}{*}{ Slaughter trait } & \multicolumn{2}{|c|}{$\begin{array}{l}\text { Experimental group with } \\
\text { Se supplementation }\end{array}$} & \multicolumn{2}{|c|}{ Control group } & \multirow{2}{*}{$\begin{array}{c}\text { Significance } \\
\text { level }\end{array}$} \\
\hline & $\mathrm{x}$ & $\mathrm{sd}$ & $\mathrm{x}$ & sd & \\
\hline Carcass weight (kg) & 79.54 & 4.0 & 84.23 & 5.94 & NS \\
\hline Lean meat content $(\%)$ & 55.89 & 3.07 & 55.75 & 3.57 & NS \\
\hline \multicolumn{6}{|l|}{ Backfat thickness (mm) } \\
\hline loin III & 26.10 & 5.97 & 25.6 & 3.57 & NS \\
\hline loin II & 16.7 & 4.80 & 16.5 & 4.74 & NS \\
\hline loin I & 24.4 & 4.52 & 24.3 & 4.19 & NS \\
\hline back & 18.8 & 4.41 & 18.2 & 4.90 & NS \\
\hline shoulder & 36.3 & 6.49 & 36.8 & 6.95 & NS \\
\hline average of 5 points & 24.46 & 2.24 & 24.28 & 3.13 & $\mathrm{NS}$ \\
\hline Thickness of gluteus muscles & 71.20 & 4.80 & 72.6 & 7.83 & NS \\
\hline
\end{tabular}

$\mathrm{x}$ - mean, sd - standard deviation; NS - statistically non-significant differences $\mathrm{P}>0.05$. 
Table 2. Meat quality results - experiment I

\begin{tabular}{|c|c|c|c|c|c|}
\hline \multirow[t]{2}{*}{ Trait } & \multicolumn{2}{|c|}{$\begin{array}{c}\text { Experimental group } \\
\text { with Se supplementation }\end{array}$} & \multicolumn{2}{|c|}{ Control group } & \multirow{2}{*}{$\begin{array}{c}\text { Significance } \\
\text { level }\end{array}$} \\
\hline & $\mathrm{x}$ & $\mathrm{sd}$ & $\mathrm{x}$ & $\mathrm{sd}$ & \\
\hline $\mathrm{pH}_{24}$ & 5.74 & 0.15 & 5.75 & 0.7 & NS \\
\hline $\mathrm{PE}_{24}(\mathrm{~ms})$ & 4.40 & 1.29 & 4.46 & 1.23 & NS \\
\hline WHC (\%) & 28.78 & 1.99 & 29.88 & 1.91 & NS \\
\hline Drip loss (\%) & 5.63 & 1.43 & 6.77 & 0.70 & $*$ \\
\hline Cooking loss (\%) & 27.56 & 4.14 & 28.99 & 2.35 & NS \\
\hline Water content $(\%)$ & 72.97 & 0.63 & 72.70 & 1.07 & NS \\
\hline Fat content $(\%)$ & 1.85 & 0.85 & 1.47 & 0.64 & NS \\
\hline Protein content $(\%)$ & 23.91 & 0.78 & 24.49 & 0.82 & NS \\
\hline \multicolumn{6}{|l|}{ Colour: } \\
\hline lightness L* & 49.21 & 1.27 & 50.68 & 2.54 & NS \\
\hline redness $\mathrm{a}^{*}$ & 4.70 & 0.62 & 4.54 & 0.94 & NS \\
\hline yellowness b* & 2.21 & 0.72 & 2.11 & 0.86 & NS \\
\hline
\end{tabular}

$\mathrm{x}$ - mean, sd - standard deviation; NS - statistically non-significant differences $\mathrm{P}>0.05$.

* - statistically significant differences $\mathrm{P}<0.05$.

Table 3. Sensory results for cooked LD muscle - experiment I

\begin{tabular}{l|r|r|r|r|c}
\hline \multirow{2}{*}{ Trait } & \multicolumn{2}{c|}{$\begin{array}{c}\text { Experimental group with Se } \\
\text { supplementation }\end{array}$} & \multicolumn{2}{c|}{ Control group } & \multirow{2}{*}{$\begin{array}{c}\text { Significance } \\
\text { level }\end{array}$} \\
\cline { 2 - 5 } & $\mathrm{x}$ & $\mathrm{sd}$ & $\mathrm{x}$ & $\mathrm{sd}$ & \\
\hline Smell (points) & 4.63 & 0.16 & 4.46 & 0.26 & $\mathrm{NS}$ \\
Juiciness (points) & 4.51 & 0.30 & 4.41 & 0.28 & $\mathrm{NS}$ \\
Tenderness (points) & 4.56 & 0.23 & 4.46 & 0.21 & $\mathrm{NS}$ \\
Flavour (points) & 4.49 & 0.18 & 4.42 & 0.22 & $\mathrm{NS}$ \\
Tenderness (WB) & 21.65 & 2.56 & 20.99 & 3.53 & \\
\hline
\end{tabular}

$\mathrm{x}$ - mean, sd - standard deviation; NS - statistically non-significant differences $\mathrm{P}>0.05$,

* - statistically significant differences $\mathrm{P}<0.05$.

\section{b. experiment II}

Based on the performed statistical analysis there were no statistically significant differences between the groups for slaughter traits. The carcasses of both groups were of similar weight (from 84 to $86 \mathrm{~kg}$ ) but they had a relatively low lean meat content (approx. 51\%). The lowest fat content was observed in carcasses from the experimental group that received organic selenium additive (average from 5 measurement points was $21.13 \mathrm{~mm}$ ) and the control group (average from 5 measurement points was $22.38 \mathrm{~mm}$ ) (Table 4). There was no PSE meat in any group. Meat from the experimental group with the organic selenium additive reached the highest value of $\mathrm{pH}_{45}$, with a statistically significant difference (Table 5). The assessment of physicochemical meat traits revealed significantly lower values of WHC in the experimental group with the organic selenium additive. It was observed that selenium content in the LD muscles of the experimental group, supplemented with inorganic selenium, was lower than in the control group. This difference was statistically significant but difficult to explain. The cooked meat sensory evaluation showed significantly better 
juiciness of meat from the group supplemented with the inorganic selenium additive than from the control group (Table 6).

Table 4. Slaughter value of fattening pigs - experiment II

\begin{tabular}{|c|c|c|c|c|c|c|}
\hline \multirow{3}{*}{ Slaughter trait } & \multicolumn{4}{|c|}{ Experimental groups } & \multirow{2}{*}{\multicolumn{2}{|c|}{ Control group }} \\
\hline & \multicolumn{2}{|c|}{ with inorganic Se } & \multicolumn{2}{|c|}{ with organic $\mathrm{Se}$} & & \\
\hline & $\mathrm{x}$ & sd & $\mathrm{x}$ & sd & $\mathrm{x}$ & sd \\
\hline Carcass weight (kg) & 86.63 & 8.53 & 84.57 & 11.29 & 84.88 & 9.37 \\
\hline Lean meat content $(\%)$ & 51.08 & 2.78 & 52.34 & 2.33 & 50.98 & 3.94 \\
\hline \multicolumn{7}{|l|}{ Backfat thickness (mm) } \\
\hline loin III & 23.53 & 5.34 & 22.80 & 3.89 & 25.69 & 7.75 \\
\hline loin II & 18.87 & 4.24 & 18.53 & 3.08 & 19.62 & 4.44 \\
\hline loin I & 29.46 & 6.62 & 27.40 & 3.91 & 31.07 & 4.65 \\
\hline back & $22.33 \mathrm{~A}$ & 5.56 & 21.00 & 3.34 & $18.00 \mathrm{~B}$ & 4.41 \\
\hline shoulder & 39.87 & 8.59 & 36.73 & 4.98 & 35.38 & 7.74 \\
\hline average of 5 points & $26.81 \mathrm{~A}$ & 4.13 & $21.13 \mathrm{~B}$ & 3.56 & 22.38 & 5.06 \\
\hline Thickness of gluteus muscles & 68.73 & 6.30 & $71.87 \mathrm{~A}$ & 4.21 & $65.45 \mathrm{~B}$ & 7.75 \\
\hline
\end{tabular}

$\mathrm{x}$ - mean, sd - standard deviation; A, B - means with different indexes are statistically significant at $\mathrm{P}<0.01$.

Table 5. Meat quality results and evaluation of physicochemical traits - experiment II

\begin{tabular}{|c|c|c|c|c|c|c|}
\hline \multirow{3}{*}{ Trait } & \multicolumn{4}{|c|}{ Experimental groups } & \multirow{2}{*}{\multicolumn{2}{|c|}{ Control group }} \\
\hline & \multicolumn{2}{|c|}{ with inorganic Se } & \multicolumn{2}{|c|}{ with organic Se } & & \\
\hline & $\mathrm{x}$ & sd & $\mathrm{x}$ & $\mathrm{sd}$ & $\mathrm{x}$ & $\mathrm{sd}$ \\
\hline $\mathrm{pH}_{45}$ & $6.32 \mathrm{~A}$ & 0.20 & $6.53 \mathrm{~B}$ & 0.24 & $6.37 \mathrm{~A}$ & 0.09 \\
\hline $\mathrm{pH}_{24}$ & $5.86 \mathrm{~A}$ & 0.06 & $5.90 \mathrm{~A}$ & 0.11 & $5.78 \mathrm{~B}$ & 0.09 \\
\hline $\mathrm{PE}_{24}$ & 6.73 & 1.25 & 6.06 & 2.11 & 6.02 & 1.96 \\
\hline WHC (\%) & $31.61 \mathrm{~A}$ & 1.67 & $34.98 \mathrm{~B}$ & 2.63 & $32.17 \mathrm{~A}$ & 1.82 \\
\hline Drip loss $(\%)$ & 4.33 & 2.27 & 3.95 & 2.56 & 4.03 & 1.80 \\
\hline Cooking loss (\%) & 32.90 & 4.07 & 29.84 & 2.34 & 30.98 & 5.11 \\
\hline Water content $(\%)$ & 72.76 & 1.03 & 72.59 & 1.06 & 72.75 & 0.81 \\
\hline Fat content $(\%)$ & 3.01 & 0.85 & 2.80 & 1.25 & 2.38 & 0.86 \\
\hline Protein content $(\%)$ & 23.14 & 0.93 & 23.09 & 1.37 & 23.76 & 0.74 \\
\hline \multicolumn{7}{|l|}{ Colour: } \\
\hline $\mathrm{L}^{*}$ & 50.41 & 3.24 & 48.55 & 4.17 & 50.76 & 2.73 \\
\hline$a^{*}$ & 6.31 & 1.26 & 6.20 & 0.2 & 6.50 & 1.04 \\
\hline$b^{*}$ & 2.29 & 1.77 & $1.41 \mathrm{~A}$ & 1.57 & $2.77 \mathrm{~B}$ & 0.96 \\
\hline Selenium content (mg) & $0.05 \mathrm{~A}$ & 0.02 & $0.09 \mathrm{~B}$ & 0.01 & $0.08 \mathrm{~B}$ & 0.01 \\
\hline
\end{tabular}

$\mathrm{x}$ - mean, sd - standard deviation; A, B - means with different indexes are statistically significant at $\mathrm{P}<0.01$.

The low level of selenium in tissues, in spite of its supplementation in feed, is an extremely puzzling fact. Selenium level in the tissues of the supplemented animals was very similar to the level naturally observed in pigs. Based on the results obtained it was impossible to establish which selenium form: organic or inorganic, was assimilated more easily. The highest selenium concentration $(0.179 \mathrm{mg} / \mathrm{kg})$ was observed in the semimembranosus muscle in the group fed with inorganic selenium form (Table 7). 
Table 6. Sensory results for cooked ML muscle - experiment II

\begin{tabular}{|c|c|c|c|c|c|c|}
\hline \multirow{3}{*}{ Trait } & \multicolumn{4}{|c|}{ Experimental groups } & \multirow{2}{*}{\multicolumn{2}{|c|}{ Control group }} \\
\hline & \multicolumn{2}{|c|}{ with inorganic $\mathrm{Se}$} & \multicolumn{2}{|c|}{ with organic $\mathrm{Se}$} & & \\
\hline & $\mathrm{x}$ & $\mathrm{sd}$ & $\mathrm{x}$ & $\mathrm{sd}$ & $\mathrm{x}$ & $\mathrm{sd}$ \\
\hline Smell (points) & 4.48 & 0.12 & 4.51 & 0.15 & 4.45 & 0.08 \\
\hline Juiciness (points) & $4.16 \mathrm{~A}$ & 0.22 & $3.94 \mathrm{~B}$ & 0.28 & 3.99 & 0.28 \\
\hline Tenderness (points) & 4.32 & 0.24 & 4.31 & 0.24 & 4.29 & 0.26 \\
\hline Flavour (points) & 4.42 & 0.20 & 4.35 & 0.16 & 4.32 & 0.17 \\
\hline Tenderness (WB) & 54.77 & 16.32 & 61.70 & 24.21 & 47.81 & 8.60 \\
\hline
\end{tabular}

$\mathrm{x}$ - mean, sd - standard deviation; A, B - means with different indexes are statistically significant at $\mathrm{P}<0.01$.

Table 7. Inorganic and organic selenium compounds distribution in chosen muscles and carcass parts - experiment II (in $\mathrm{mg} / \mathrm{kg}$ )

\begin{tabular}{|c|c|c|c|c|c|c|}
\hline \multirow{3}{*}{ Carcass part } & \multicolumn{4}{|c|}{ Experimental groups } & \multirow{2}{*}{\multicolumn{2}{|c|}{ Control group }} \\
\hline & \multicolumn{2}{|c|}{ with inorganic $\mathrm{Se}$} & \multicolumn{2}{|c|}{ with organic Se } & & \\
\hline & $\mathrm{x}$ & sd & $\mathrm{x}$ & sd & $\mathrm{x}$ & sd \\
\hline m. longissimus & $0.073 \mathrm{~A}$ & 0.022 & $0.094 \mathrm{~B}$ & 0.026 & $0.078 \mathrm{~A}$ & 0.018 \\
\hline$m$. biceps femoris & $0.087 \mathrm{~A}$ & 0.023 & $0.078 \mathrm{~A}, \mathrm{~B}$ & 0.019 & $0.068 \mathrm{~B}$ & 0.016 \\
\hline m. semimembranosus & $0.179 \mathrm{~A}$ & 0.035 & $0.075 \mathrm{~B}, \mathrm{C}$ & 0.021 & $0.053 \mathrm{C}$ & 0.023 \\
\hline m. triceps brachii & $0.084 \mathrm{~A}$ & 0.022 & $0.072 \mathrm{~A}$ & 0.019 & $0.046 \mathrm{~B}$ & 0.018 \\
\hline Bacon & $0.079 \mathrm{~A}$ & 0.019 & $0.086 \mathrm{~A}$ & 0.021 & $0.052 \mathrm{~B}$ & 0.015 \\
\hline Backfat & 0.059 & 0.022 & 0.070 & 0.020 & 0.058 & 0.019 \\
\hline Neck & $0.083 \mathrm{~A}$ & 0.023 & $0.093 \mathrm{~A}$ & 0.021 & $0.051 \mathrm{~B}$ & 0.018 \\
\hline Kidneys & $2.014 \mathrm{~A}$ & 0.045 & $2.313 \mathrm{~B}$ & 0.039 & $2.025 \mathrm{~A}$ & 0.035 \\
\hline Liver & $0.591 \mathrm{~A}$ & 0.035 & $0.641 \mathrm{~B}$ & 0.020 & $0.678 \mathrm{~B}$ & 0.052 \\
\hline
\end{tabular}

$\mathrm{x}$ - mean, sd - standard deviation; A, B, C - means with different indexes are statistically significant at $\mathrm{P}<0.01$.

\section{Discussion}

The research results have proved the lack of a negative impact of selenium supplementation on slaughter value. Other authors have reported similar conclusions (Han and Thacker, 2006; Kim and Mahan, 2001 b; Bobcek et al., 2006; Mahan et al., 1999). Han and Thacker (2006) observed slightly lower backfat thickness in the carcasses of pigs fed with organic selenium additive, and this was also confirmed in the present research. Zhan et al. (2007) reported that the supplementation of organic selenium in the amount of $0.045 \mathrm{mg} / \mathrm{kg}$ of feed caused an increase in the meat colour parameter a* and also lower drip loss value. Similar results were obtained by Bobcek et al. (2006). Han and Thacker (2006) did not report any positive selenium impact on meat colour. In the present research lower meat drip loss was noticed in the group fed with the organic selenium additive. Such an effect was not observed when supplementing $0.03 \mathrm{mg} / \mathrm{kg}$ of feed with inorganic selenium (Zhan et al., 2007). Mahan et al. (1999) found a higher drip loss in the meat of fatteners fed with inorganic selenium additive. Zhan et al. (2007) also noticed a higher selenium level in the experimental 
group fed with the selenium additive. Also, selenium concentration was significantly higher when the organic form of this element was supplemented in the feed.

Most of these observations were not confirmed in the present research. The highest concentration of selenium from the chosen muscles was observed in the semimembranosus muscle when supplementing the diet with the inorganic form of selenium.

Li et al. (2011) noticed that the higher the selenium supplementation, the lower the drip loss. When selenium was added at $0.3 \mathrm{mg} / \mathrm{kg}$ of feed, drip loss was $3.09 \%$. Selenium added at $3 \mathrm{mg} / \mathrm{kg}$ of feed corresponded to $2.52 \%$ of drip loss. Li et al. (2011) also investigated the impact of selenium supplementation on the expression of the genes responsible for Se metabolism. The authors have indicated improved WHC of meat from the group of fatteners receiving the organic selenium additive. These relations were not confirmed by the present research. For the group of fatteners fed with the inorganic selenium form, the highest selenium concentration $(0.179 \mathrm{mg} / \mathrm{kg})$ was observed in the semimembranosus muscle.

Research performed by many authors has indicated an improvement of meat stability and colour caused by the antioxidative effect of organic selenium forms. This antioxidative effect was observed mainly due to the increased activity of specific enzymes that are responsible for lipid oxidation. Supplementing inorganic forms of selenium might have negative effects (Zhan et al., 2007; Daun and Akesson, 2004). When inorganic selenium forms are of too high a concentration they may cause myopathy, increased plasma glutamic oxaloacetic transaminase activity and clinical signs of toxicity, including paresis, trembling, and ataxia (Kim and Mahan, $2001 \mathrm{a}$ ). The research described above did not prove that the influence of selenium on meat colour was statistically significant. The results obtained in the experimental groups for colour lightness $\mathrm{L}^{*}$ and for $\mathrm{a}^{*}$ and $\mathrm{b}^{*}$ coordinates were similar to those reported by Zhan et al. (2007).

Zagrodzki (2000) reported selenium content in pork ranging from 0.033 to 0.502 $\mathrm{mg} / \mathrm{kg}$ and stated that selenium level in pork depends greatly on selenium traces in soil. In the following research the tendency to accumulate organic and inorganic selenium in tissues was irregular and difficult to explain. Mahan et al. (2005) indicated that supplementing organic selenium in feed caused higher selenium concentration in tissues. Similar selenium concentration in the longissimus of fatteners fed with the inorganic form and of fatteners from the control group was observed. This brought about the question concerning how selenites are accumulated in pigs and whether it is legitimate to supplement them in feed. Chen et al. (2006) indicated that every single supplementation of selenium, regardless of its form, resulted in higher selenium content in muscle tissue. Many authors, however, indicated better assimilability of organic selenium forms (Mahan et al., 1999; Li et al., 2011; Bobcek et al., 2006). In the present research the highest selenium concentration was found in the semimembranosus muscle of pigs receiving the inorganic selenium additive.

The study results indicate that there was no impact of dietary selenium supplementation on slaughter value, meat quality and some physicochemical and sensory characteristics of meat. However, lower meat WHC of fatteners receiving the organic selenium additive was observed. 
The results obtained were ambiguous and indicated that there was no distinct trend in storing selenium in animal tissues. Hence, further research is necessary and it seems that testing different options and increasing selenium supplementation of pig feeds is also needed.

\section{References}

B obcek R., B obcek B., L' A huncky R., Mrazova R. (2006). Pig meat indices as influenced by increased levels of organic selenium. Ann. Anim. Sci., Suppl. 2/1: 245-249.

Che n L.Q., Zh a o J., Shu ip ing L., D eng G., L i B., Zh ang P., Ch a i Z. (2006). Accumulation of mercury, selenium and their binding proteins in porcine kidney and liver from mercury-exposed areas with the investigation of their redox responses. Sci. Total Environ., 366: 627-637.

D a u n C., A ke s s o n B. (2004). Comparison of glutathione peroxidase activity, and of total and soluble selenium content in two muscles from chicken, turkey, duck, ostrich and lamb. Food Chem., 85: 295-303.

Dę b s k i B. (2007). Evaluation of selenium level in animals in Poland. In: Selenium - an element that matters to health and fascinates researchers (in Polish). Malamut, Warszawa, pp. 103-126.

Ghany Hefnawy A.E., Tórtora-Pére z J.L. (2010). The importance of selenium and the effects of its deficiency in animal health. Small Ruminant Res., 89: 185-192.

G r a u I., H a m m G. (1956). Die Bestimmung der Wasserbindung des Fleisches mittels der Preßmethode. Fleischwirtschaft, 8: 733-734.

Han Y.K., Thacker P. (2006). Effects of L-carnitine, selenium-enriched yeast, jujube fruit and Hwangto (red clay) supplementation on performance and carcass measurements of finishing pigs. Asian J. Anim. Sci., 34: 85-93.

Hath c ock J. (2004). Selenium. Vitamin and mineral safety, 2nd edition. Council for Responsible Nutrition (CRN).

Hordyjewska A., Pasternak K. (2004). Selenium and its role in the human body (in Polish). Bromat. Chem. Toksykol., 37: 9-18.

K i m Y.Y., M a h a n D.C. (2001 a). Comparative effects of high dietary levels of organic and inorganic selenium on selenium toxicity of growing-finishing pigs. J. Anim. Sci., 79: 942-948.

K i m Y.Y., M a h a n D.C. (2001 b). Prolonged feeding of high dietary levels of organic and inorganic selenium to gilts from $25 \mathrm{~kg}$ body weight through one parity. J. Anim. Sci., 79: 956-966.

Li H.G., Z hou J.Ch., Zh a o H. (2011). Enhanced water holding capacity of meat was associated with increased Sepw1 gene expression in pigs fed selenium-enriched yeast. Meat Sci., 87, 2 : 95-100.

Mahan D.C., Brende muhl J.H., Carter S.D., Chiba L.I., Crenshaw T.D., Cromwe 11 G.L., D o v e C.R., H a r p e r A.F., H 111 G.M., Holl is G.R., K i m S.W., L in d e m a n n M.D., Maxwell C.V., Miller P.S., Nelssen J.L., Richert B.T., S outhern L.L., Stahly T.S., Ste in H.H., van Heugten E., Yen J.T. (2005). Comparison of dietary selenium fed to grower finisher pigs from various regions of the United States on resulting tissue Se and loin mineral concentrations. J. Anim. Sci., 83: 852-857.

Ma h a n D.C., C l in e T.R., R i c h e r t B. (1999). Effects of dietary levels of selenium-enriched yeast and sodium selenite as selenium sources fed to growing-finishing pigs on performance, tissue selenium, serum glutatione peroxidase activity, carcass characteristics and loin quality. J. Anim. Sci., 77: $2172-2179$.

Marzec Z., Marzec A., Z aręba S. (2002). Meat and meat products as a source of selenium in daily food rations (in Polish). Med. Weter., 58: 705-707.

W ą sow i c z W., Gromadzińska J., Ry dzyński K., To m c zak J. (2003). Selenium status of low-selenium area residents: Polish experience. Toxicol. Lett., 137: 95-101.

Z a grodzki P. (2000). Selenium in human nutrition. Part I. Selenium content in the food, recommended and actual intakes of selenium (in Polish). Bromat. Chem. Toksykol., 33: 209-214. 
Zhan X., Mhang W., Zha o R. (2007). Effects of different selenium sources on selenium distribution, loin quality and antioxidant status in finishing pigs. Anim. Feed Sci. Tech., 132: 202-211.

Accepted for printing 19 VI 2013 